\title{
Teorie en praktyk van die prediking in die Nuwe Testament: Walter Schmithals aan die woord
}

\author{
P B Boshoff \& A G van Aarde \\ Universiteit van Pretoria
}

\begin{abstract}
Theory and practice of preaching according to Walter Schmithals

This article aims to show what Schmithals understands by preaching and how he applies it in practice. The argument develops along the following lines:

* Theory of preaching.

* Meditation: reception of the sermon.

- The role of the historical situation of the biblical text in preaching.

It will be shown that Schmithals succeeds in creating unity between historical and dogmatic exegesis.
\end{abstract}

\section{INLEIDING}

Volgens die lesingopgawe van die Universiteit van Marburg het Walter Schmithals in die wintersemester van 1964/1965 die eksegese van voorgeskrewe preekperikope as lesingopdrag op hom geneem. Dit was sy antwoord op die normale klagte en vraag en implisiete kritiek van teologiestudente, naamlik: 'Watter nut het al die oefeninge van die histories-kritiese metode vir ons in die praktyk van die kerk?' In die volgende wintersemester het sy kollega en Ou-Testamentikus, Gunneweg, by hom aangesluit in die werkgemeenskap van eksegese en verkondiging. Nadat beide van Marburg af weg is (Schmithals is na Berlyn en Gunneweg na Bonn). het hulle die

\footnotetext{
- Hierdic artikel is gebasecr op 'n hoofstuk van die proefskrif (1991), 'Die eenheid van die historiese en die teologiese verstaan van die Nuwe Testament by Walter Schmithals'. Dit is ingedien onder promotorskap van prof dr A G van Aarde en mede-promotorskap van dr G M M Pelser, as deel van die vereistes vir die DD-graad (Nuwe-Testamentiese Wetenskap), Fakulteit Teologie (Afd A), Universiteil van Pretoria.
} 
werk ter plaatse voortgesit en ook gereeld met groepe studente bymekaar gekom om die weg van eksegese tot prediking te voltrek. Die laaste, sewe en veertigste byeenkoms het van 8 tot 10 Julie 1988 in Bonn plaasgevind. Gewoonlik is vier tekste, twee uit die Ou Testament en twee uit die Nuwe Testament, uitgelè waarna Schmithals of Gunneweg dan oor een van die tekste in 'n erediens gepreek het. In die afsluitende diskussie kon die groep herkou aan die weg wat gevolg is.

Die wyse waarop Schmithals en Gunneweg die werk aangepak het, was om die studente in te lei in die verstaansproses waarin die betrokke teks daadwerklik verstaan word sodat dit tot 'n verstaanbare preek kan lei. Op geen beter manier kan getoon word dat die histories-kritiese eksegese nuttig en noodsaaklik is om die verkondigingstaak te verrig nie.

Wat die student van sy professor wil weet, is of hy kan preek soos hy teologies dink. Is daar 'n natuurlike oorgang tussen teologie en prediking? Wat die vraag akuut maak, is die algemene indruk dat daar 'n groot afstand tussen die resultate van die historiese eksegese en die Sondagse prediking bestaan. Preke kom èrens anders vandaan as uit die eksegese. Schmithals het hom verbind tot die historiese eksegese as die enigste metode wat in pas met moderne insigte is. Dat hy hom ook daarop toelê om aan te toon dat die eksegese met die oog op prediking gedoen word en tot op die drumpel van preek kom, maak dit die moeite werd om een myl saam met hom te loop.

Die metode wat ons volg, is om na te gaan wat Schmithals as die taak van die prediking beskou en daarna voorbeelde te bespreek waar hy en andere hierdie taak uitvoer.

\section{TEORIE VAN DIE PREDIKING}

Die algemene onbehae met die resultate van die histories-kritiese eksegese en die skynbare onmoontlikheid om 'n gangbare brug tussen die Skrif en die verkondiging van die Bybelse boodskap te lê, maak dat die tradisionele preekteorie, waarvolgens prediking eksegese en toepassing van die Skrif is, in die gedrang kom. Dreyer (1989:359-360) formuleer van die redes wat tot hierdie gedrang aanleiding gee: Aan die een kant is uitgewys dat daar in die Bybel verskillende teologiee is en dat die Bybelse outeurs met verskillende begrippe van God werk. Daarom sou dit nie so eenvoudig wees om God in die prediking aan die woord te stel nie, want Hy word in die Bybel so verskillend geteken. Aan die ander kant word die oorbring van die boodskap van die teks moeilik gemaak deur die historiese afstand tussen die hoorders van vandag en die omstandighede waarin die teks aanvanklik gespreek het. 
Die diversiteit van teologieë in die Bybel is vir Schmithals egter nie 'n rede tot verleentheid en 'n grond waarom die kerk sprakeloos in die wêreld moet wees nie. Hy los nie die probleem op deur 'n eenvoudige eenheidseksegese van die Skrif aan te beveel nie. Hy erken voluit die verskille in die teologieë van byvoorbeeld Paulus en Johannes en nog verder tussen Luther en Barth. Elkeen het sy eie begrippe waarin hy die heil verkondig. Elkeen het sy eie begrip van God. Maar dit beteken nie dat hulle mekaar uitsluit nie. Hulle praat van een en dieselfde Goddelike handeling en bring dieselfde menslike grondhouding vir sy eie tyd en omstandighede onder woorde. Die Bybelse Kanon het nie net een teologie nie, maar verkondig net een evangelie in verskillende teologiese ontwerpe (Schmithals 1967b:494; 1970a:60; 1970c: 181). Dit beteken egter nie dat die een boodskap van die Skrif die vertrekpunt van die Bybelondersoek is nie; dit is eerder die resultaat daarvan (Schmithals 1967c:204).

Schmithals se teologiese arbeid as geheel is net te begryp onder die veronderstelling van die historiese bewussyn. Wanneer die kerk vandag verantwoordelik wil spreek, is die wetenskaplike, dit wil sê die histories-kritiese bedinking van die Skrifwoord ' $n$ onvervangbare voorwaarde daarvoor. Die Skrif is mensewoord en moet op 'n menslike manier deur mense verstaan word, dit wil sê die betekenis daarvan moet hier en nou tot uitdrukking gebring word. Daar kom in werklikheid geen kommunikasiegaping tussen die histories-kritiese eksegese en die oordra daarvan in die eksistensiale interpretasie nie. Eksegese is bevredigend, want daardeur begin die teks in die hede te praat. Van die begin af word die teks in die hede, hier en nou, verstaan. Dat hierdie werkwyse moeilik deur te voer is, is nog geen regverdiging om daarvan afstand te doen nie. Geen ander werkwyse is onder die voorwaardes van die historiese bewussyn wetenskaplik verantwoordbaar nie (vgl Schmithals 1970a:52-54; 1970b:84).

Dat die Skrif mensewoord is wat menslik verstaan word, beteken dat geloof nie 'n vooronderstelling vir die verstaan van die Bybel gemaak kan word nie. 'Verstaan' behoort ook nie aan geloof as die gawe van die Heilige Gees gelyk gestel te word nie. Dit sou beteken dat teologie en eksegese net as geloofswetenskap moontlik is, wat die wetenskaplike karakter van die teologie in die gevaar stel. Die neiging by so 'n gelykstelling is gewoonlik dat die wetenskaplike arbeid as oorbodig beskou word (vgl Schmithals 1970a:60; 1970b:84-85).

In sy homiletiese besinning beweeg Schmithals (1967a:96) binne die bane van die tradisionele homiletiek wat voor die preek van die prediker eksegese en meditasie verwag. In die eksegese hou die prediker hom besig met die teks en in meditasie besin hy oor die hoorders van die preek. Onder meditasie of toepassing van die Skrif verstaan Schmithals nie dat die hoorders opdragte kry oor hoe om hulle geloof 
uit te leef nie, maar dat die hoorder deur die teks met homself gekonfronteer word. Die hoorder word uitgehaal uit die selfverstaan waarin hy leef en tot geloof geroep. Die preek mag nie 'n lewensvreemde lesing wees nie. Verder word 'n teks gepreek sodat die preek inhoud en gesag kan hê. Die onderskeid tussen eksegese en meditasie word metodies gemaak, maar in die praktyk is dit nie twee afsonderlike stappe nie. Vanuit die situasie van die prediker en gemeente duik bepaalde aktualiseringsmoontlikhede van die teks op. En die eksegese lê gedagtes bloot wat vra om gepreek te word. Die teks word vanuit die situasie benader en vanuit die teks word die situasie benader.

Wat die peiling van die situasie betref, meen Schmithals (1967a:96-97; 1972b: 194) dat die prediker baie van die sosiologie elı sielkunde kan leer. Maar vir die predikant bly dit 'n eie opgawe om die spesifieke mense vir wie hy preek, te leer ken:- Hy moet hulle lewenswerklikheid ervaar. Hy moet huisbesoek doen, hulle werksomstandighede ken, weet wat hulle dink en watter sondes hulle doen. Die bedoeling is egter nie dat die mense se probleme en behoeftes so ter sprake gebring moet word dat hulle hulleself objektiverend as mense met probleme sien nie, maar eerder so dat hulle selfverstaan in hulle behoeftes bevraagteken word (Schmithals 1970a:56; 1973:125).

Die Bybelse tekste is vir Schmithals (1970a:25, 46-47, 51) die enigste grondslag vir die prediking, want daarin is die getuienis van die Goddelike openbaring. Die Skrif bind die kerk aan die oorspronklike sdak: Jesus Christus. Die saak waarvan die ou tekste getuig, bly onaangetas, al kyk die nuutste wetenskap meer gedistansieerd daarna. Schmithals kan geen toegewing maak dat die gesag van die Skrif aangetas sou wees nie (vgl Dreyer 1989:359). Die Skrif roep die kerk toe dat die eskatologiese heilshandeling van God die daad is waardeur God die kerk in die lewe roep en stel die kerk daarmee in verband. Die sola Scriptura bewaar die solus Christus en bewaar die kerk (vgl Schmithals 1980a:18).

As gesagsvorm vir die kerk en die teologie is die kanon vir Schmithals (1970a: 45) van primêre belang. Gewoonlik word die organisasie van die kerk en die leerstuk van die Heilige Gees ook genoem as gesagsvorme. Maar die Skrif geniet voorrang bo die kerkorganisasie en die Heilige Gees, want met die kanonvorming het die kerk teruggegryp na die eerste getuienisse aangaande die grondliggende Christus-gebeure en word die kerk vir die toekoms by hierdie fundamentele insig bewaar. Van Selms meen weer dat die Heilige Gees voorrang geniet en aan die kanon en die kerk voorafgaan. Die Heilige Gees maak mense tydgenote van die heilstyd, sonder dat enige historiese hulpmiddele nodig is. 'Door de werking van de Heilige Geest wordt men bij het lezen van het Evangelie tot discipel-tijdgenoot' (Van Selms 1951: 273). Maar hierdie formulering is eerder 'n onderskrywing van Schmithals se stand- 
punt omdat 'bij het lezen van het Evangelie' wys op die noodsaak en die voorrang van die historiese middel, die kanon. Die omgang met die eerste draers van die oorlewering is nie nodig nie, maar van die oorlewering self kan nie afgesien word nie.

Opsommenderwys kan ons die wese van die prediking, soos Schmithals dit beskryf en beoefen, tot ' $n$ formule reduseer: Prediking is die teenwoordig stel van die teks (vgl Scmithals 1967a:96). Die bedoeling van die teks is om die kerk op sy blywende oorsprong, die Christus-belydenis, te grond. En die saak van die teks is daarop uit om geloof by die leser te stig en daarom dring dit tot verkondiging.

'n Mens kan aanvaar dat daar eenstemmigheid onder teoloê is dat prediking formeel op die Skrif gebaseer moet wees. Dit beteken egter nie dat daar eenstemmigheid oor die uitkoms van die verhouding tussen teks en preek is nie. Die beweging van teks tot preek word bepaal deur die begrip wat elkeen van prediking het. Wat is die wesenlike inhoud van die prediking? Wat moet die prediking bereik? Op hierdie vrae antwoord Schmithals (1981:26) dat dit in die Christelike erediens gaan om die toesegging van die vergewing van sondes. Dit is die een ding wat nodig is. Hy sal dus in die tekste soek na dit wat daar oor die mens as sondaar gesê word en oor die aanvaarding van die sondaar deur God. Indien 'n mens die prediking verstaan as ' $n$ begeleiding van mense wat reeds vergewing van sondes ontvang het en nou verder moet gaan (vgl Oberholzer 1990:654), sal hy in die tekste na sulke mense soek en na gedragsaanwysings vir mense in hierdie posisie. Die verstaan van wat prediking is en die verstaan van die teks beïnvloed mekaar wedersyds.

Waar Oberholzer (1990:654) twee preekinhoude wil aantoon, een vir die nieChristelike wêreld en een vir die Christelike wêreld, dit wil sê, een vir vóór die ontmoeting en een vir ná die ontmoeting met God, meen Schmithals (1953:535; 1979: $99,322,711)$ dat die preekinhoud in beginsel altyd dieselfde bly. Alle preke is omskrywing van die heilshandeling van God in Christus. Alle preke verkondig die een evangelie: 'Die tyd is vervul en die heerskappy van God het naby gekom' (Mark 1:15); 'Moenie vrees nie, Ek is by jou' (Jes 43:5); 'Jy het net my genade nodig, want die krag kom in swakheid tot voleinding' ( 2 Kor 12:9). Net die mens wat in die luister ophou om die heil van homself te verwag, kan die preek hoor. Die evangelie word gehoor deur die mens wat weet van sy eie onheil en bereid is om ontvanger, bedelaar te wees. God kom na die ootmoediges toe.

Schmithals (1980b:102-103) verstaan geloof nie as 'n verowerde sekerheid nie. Geloof beskryf nie 'n toestand waarin die mens verkeer nie. Die evangelis Johannes se uitdrukking van 'bly' soos in 'as julle in my woord bly' (Joh 8:31) wil juis nie 'n statiese toestand aandui nie, maar beklemtoon die tydelike aspek, naamlik dat dit om getrouheid gaan. Geloof is eerder 'n opdrag as 'n besitting. Met sy wandel' in die Gees (Rom 8:4) gee Paulus aan dieselfde gedagte uitdrukking. Vir die geloof is 
dit duidelik dat ons sondaars is en dat die mag van die sonde nie onderskat moet word nie. In Christus se woorde aan die kruis, 'My God, my God, waarom het U My verlaat?' (Mark 15:34) word die menslike lewe coram Deo beskryf (Schmithals 1979: 698). As sondaar gaan die oordeel van God oor die mens, ('waarom het $U$ my verlaat?') en God tree die mens tegemoet wat hierdie oordeel oor Hom aanvaar ('my God, my God'). Die genade volg nie op die oordeel nie, maar oordeel en genade val saam. Oordeel en genade vorm 'n dinamiese eenheid en bly in hierdie eenheid. Oordeel en genade weerspreek mekaar nie, maar bepaal mekaar wedersyds. Die mens kom tot sy ware menslikheid waar oordeel genade word. Die genade wat die mens ontvang, is nie van so ' $n$ aard dat die mens dit vir altyd het en nie weer daaruit kan val nie. Die Nuwe-Testamentiese fenomeen 'sonde' bly die 'onmoontlike moontlikheid' van die mens solank as wat die genade in die woord van die kruis aan hom verkondig word. As nie-gelowige ontvang die mens geloof (Schmithals 1979: 173; 1980b:102). In die dinamiese eenheid van oordeel en genade handhaaf Schmithals die theologia crucis teenoor die theologia gloriae, waarvolgens iemand wat eenmaal genade ontvang het nie weer onder die oordeel van God kom nie. Schmithals $(1975: 1-4 ; 1979: 474 ; 1988: 374)$ is oortuig dat die kanonieke boodskap van die kerk, onder andere, deur die theologia crucis verwoord word.

In die verkondiging word die oordeel en genade teenwoordig gestel (Schmithals 1979:123, 712-713). Die mens hoor dat sy eie moontlikhede nie aan hom die lewe kan gee nie; God bied hom die lewe as geskenk aan. Die sin van die verkondiging hang saam met die theologia crucis deurdat die mag van die sonde in 'n persoonlik geldende woord in die lewe van die konkrete mens gebreek word. Die uitsigloosheid van die menslike moontlikhede word nie deur 'n teorie blootgelê nie, maar deur die teenswoordige woord wat die genade van God aan die mens toesê. Prediking is heilsgebeure. Woord en heil val saam. Heil is net in die verkondiging teenwoordig (Schmithals 1970b:83; 1988:264). Die geloof ontstaan as gehoorsaamheid aan die verkondigende woord, wat die Christus-gebeure as die Goddelike heilshandeling uitroep (Schmithals 1979:1 19; 1988:382).

Schmithals bly by die teks, dit wil sê hy bly georiënteer aan die Bybelse getuienis om op hierdie wyse teenswoordige Christelike heil moontlik te laat word. Volgens die Christelike geloof is daar net een openbaring van God en dit is die Christus-gebeure. Hierdie gebeure maak dit duidelik dat God die mens se heil is. Die ter sprake bring van die teks bewaar die teologiese karakter van die prediking. Op geen ander manier kan die prediking woord van God wees nie. Wanneer prediking wegbeweeg van die eksegese en verklaring van 'n teksgedeelte, wat maklik 'n bloot formeel-wetenskaplike karakter aan die prediking kan verleen' (Dreyer 1989:365), is die teologiese karakter daarvan in gevaar. As die wegbeweging plaasvind omdat die 
eksegese en verklaring nie behoorlik deurgevoer kan word nie, soos blyk uit Dreyer (1989:365) se begronding, naamlik dat dit van die preek 'n lesing maak, is die wegbeweeg so onnodig. Wat nodig is, is nie om die teks te los nie, maar om die eksegese verantwoordelik deur te voer, want in die voltrekking daarvan begin die teks in die hede te praat.

Schmithals is nie oorhaastig met die inbring van die Heilige Gees nie. Die maak van 'n preek is mensewerk, waarop daar net soveel seën rus as op enige ander mensewerk. Die Heilige Gees beïnvloed nie op misterieuse wyse die historiese eksegese nie. Van die prediker kan verwag word dat hy vlytig sy werk sal doen en die teks aan die hand van wetenskaplike metodes sal verstaan. As die eksegese nie die betekenis van die teks in die hede kan blootlê nie, sal gebed dit ook nie doen nie. Die teologiese karakter van die prediker se werk word deur die voorwerp, die teks, waarmee hy werk, gegee en nie deur sy eie geloof bygevoeg nie. Dat die preek ook effektief sal wees en geloof stig, is nie meer die werk van die prediker nie, maar God se werk. Hy skenk die geloof waar dit gaan om instemming met dit wat in die teks gesê word. Binne die raamwerk van Reformatoriese en Bybeise teologie tree die Heilige Gees eers hier op as die verligter van die woord (Schmithals 1967b:495; 1970a:60; 1970b:83). Schmithals is nie daarop uit om die gesag van die prediking te fundeer nie. Hierdie gesag behoort eerder gerespekteer as gefundeer te word.

Uit die algemene aanvaarding dat die Heilige Gees die geloof skenk, het Dreyer (1989:361-365) die foutiewe afleiding gemaak dat, wat bekend staan as 'pneumatiese eksegese', die regte manier is om die Skrif te verstaan. Die teenwoordig stel van die teks, wat Schmithals as nugtere wetenskaplike arbeid beskou, waarvan die prediker rekenskap moet kan gee, skryf Dreyer toe aan die misterieuse werking van die Heilige Gees. Die verstaanshorisonne versmelt wanneer die inspirasie van die Bybelteks die prediker en die hoorders verlig het. 'n Mens sou Dreyer se pneumatiese eksegese miskien 'n versigtige een kon noem, want hy waarsku dat 'die eksegese bly die norm vir die gedagtes wat in die proses loskom' (Dreyer 1989:362). Ter wille van groter duidelik oor die sake wat hier aan die orde is, kan ons noem dat Dreyer nie onderskei tussen die verstaan van die teks en die glo van die boodskap nie, of om dit anders te stel, tussen wat die prediker sê en wat God sê nie. Volgens die standpunt wat Schmithals huldig, word die eer juis aan God gegee deur hierdie onderskeid te maak. Die mens kan verstaan, maar God skenk die geloof. Die prediker kan preek, maar hy bereik nooit die erns van God self nie (vgl Bultmann 1926: 44-45). Dreyer bring die groot erns reeds by die eksegese en meditasie in. Reeds hier is die Heilige Gees vir hom die inspirator en illuminator (Dreyer 1989:363). Hiervolgens is daar 'n direkte kontinuïteit tussen wat die prediker sê en wat God sê. Die prediker het 'n direkte outoriteit oor die woord van God. Schmithals teologi- 
seer nie in die raamwerk van so 'n theologia gloriae nie. As prediker het hy geen direkte outoriteit oor die woord van God nie; die Heilige Gees moet die wonder laat plaasvind dat mense hierdie verkondiging hoor as woord van God.

In sy standpunt is Dreyer gevolg deur Oberholzer (1990:654) wat prediking definieer as ."n pneumatologiese woordgebeure waarin 'n persoon wat self 'n gelowige is, via 'n kommunikasie-ervaring met 'n Skrifteks, mense begelei tot ' $n$ ontmoeting met en 'n lewe voor die lewende God'.

In hierdie definisie is die Bybelse tradisie agter die horison ingeskuif om plek te maak vir 'n sogenaamde pneumatiese ervaring. Prediking is hiervolgens in die eerste plek die appèl van die bekeerde tot die onbekeerdes en in die tweede plek die stigtelike woord van 'n vrome tot ander vromes tot bevestiging van hulle gemeenskaplike inspirasie. Nuut is hierdie siening van die prediking glad nie; in Frans word dit 'sermons de sanctification et d'appèl' genoem (vgl Vinet 1875:11).

Volgens Schmithals (1984) onderskei die Heilige Gees tussen die menslike en die Goddelike moontlikhede. Die Gees lề die mens se eiegeregtigheid bloot en lei hom na God se geregtigheid toe. Dit is die geopenbaarde geheim wat die Skrif verkondig. Ander geheime is daar nie in die Bybel nie (vgl Schmithals 1970b:85). So meen Schmithals om die Gees in ooreenstemming met die Skrif te formuleer. Die Gees kan net in ooreenstemming met die Skrif geformuleer word. Die Gees wat nodig is om die Skrif te verstaan, is net in die Skrif te vind (vgl Engelbrecht 1982: 63). Net deur die kanon kan die geeste beproef word.

Diegene vir wie die grondprobleem van die homiletiek die vraag is hoe die prediking die woord van God kan wees of is (vgl Dreyer 1989:350), sal die beskrywing, naamlik dat prediking die teenwoordig stel van die teks is, nie bevredig nie. Dit sal egter al help as mens onder 'woord van God' nie verstaan dat die menslike gesant uitgesluit word en God voorgestel word as staande teenoor die mens, terwyl Hy met hom praat in oordele en genade nie, maar so dat egte lewensmoontlikhede aan die mens getoon word uit sy dwaalweë en doodloopstrate. Maar hiermee is die probleem nog nie opgelos nie, want die aantoon van egte lewensmoontlikhede is nog nie genoeg nie, dit moet ook aangegryp word. Antropologies gesproke word die egte lewensmoontlikheid net in die konkrete menslike eksistensie werklikheid. Dogmaties gesproke is dit die werk van die Heilige Gees dat die hoorder van die preek God self hoor aanspraak maak op hom en homself gewonne gee. Die prediker is dus ontslaan van die sogenaamde grondprobleem van die homiletiek. Op geen manier kan hy waarborg dat die preek ook die woord van God sal wees nie. Prediking kan nie aan die woord van God identies gestel word nie. In vertroue dat God self sal ingryp en sy woord God se woord laat wees, stel hy die teks teenwoor- 
dig. Langs hierdie weg word die karakter van die woord van God as God se woord bewaar (vgl Schmithals 1967c: 199).

Die woordkarakter van die kanon, naamlik dat die openbaringswaarheid in bepaalde omstandighede verkondig is, moet die oê daarvoor oopmaak dat die Bybelse waarheid mense telkens in die geskiedenis tegemoet tree. Die waarheid kom en gaan, God is vry om Hom bekend te maak wanneer $\mathrm{Hy}$ wil. Die waarheid is eksistensieel, in actu. So word die woordkarakter van die woord van God bewaar. Die Bybelse waarheid het nie die karakter van 'n dogmaties-tydlose waarheid nie. Die krisis waarin die historiese Bybelwetenskap die kerk inlei, is wesenlik die krisis rondom die waarheidsbegrip. Waarheid as onhistoriese objektiwiteit moet plek maak vir die historiese waarheid, waarheid wat in die menslike geskiedenis werklikheid word waar mense tot geloof kom (Schmithals 1967c: 199, 207).

By wyse van 'n opsomming en afronding: Die term 'dialektiese teologie' beskryf die insig onder teoloë dat die waarheid histories is. 'Dat God genadig is' is nie 'n tydlose waarheid nie, nie 'n direkte waarheid nie, maar is waar in die menslike aanvaarding van sy genadedaad (vgl Bultmann 1972:117; Schmithals 1972a:76). 'n Mens sou kon sê 'dialektiese teologie' beskryf die insig in die aard van die openbaring, naamlik dat dit geschichslich is en nie absoluut nie. Die uitdrukking 'teologie van die woord', waarvoor Schmithals 'n voorkeur toon, heskryf die insig in die wyse van openbaring, naamlik dat die kerk en die verkondiging deel van die heilsgebeure uitmaak (vgl Schmithals 1972c:122). Die evangelie bereik die mens in ' $n$ verbygaande verduideliking. Die formulering van die evangelie is altyd tydelik, maar nogtans genoegsaam. Die benaming 'teologie van die krisis' beskryf die insig in die inhoud van die openbaring, naamlik dat God se handeling nie na menslike maatstawwe gerig is nie; Hy oordeel anders as die mens, Hy bring die menslike selfverstaan in ' krisis (vgl Schmithals 1972b:191, 195-196). Hierdie drie terme belig almal een saak. Die insig in hierdie saak gaan aan die histories-kritiese arbeid vooraf en vorm die grondslag daarvoor, want dit maak die eksegeet ontvanklik vir wat die teks te sê het (vgl Bultmann 1972:118; Schmithals 1970a:52-53).

Vir Schmithals is die adekwate homiletiese vraag 'n praktiese aangeleentheid: Hoe kan ek hierdie teks preek? Uit Schmithals se preekpraktyk blyk dit dat hy die krisis wat die bepaalde teks vir die menslike selfverstaan berei, uitlig en tot uitdrukking bring. So word aan die hoorders die aanleiding gegee om hulleself nuut te verstaan as mense vir wie God se genade nou geld.

As voorbeeld van die krisis wat ' $n$ bepaalde Bybelteks vir die menslike selfverstaan inhou, kan Schmithals (1986) se hantering van Johannes 14:19b dien: 'Ek lewe en julle sal lewe.' Hy behandel die teks nie soseer as 'n konkrete aanspraak tot iemand nie, maar eerder as 'n leerstuk in samehang met die Johannesevangelie wat 
die moontlikheid het om in 'n konkrete gemeente aanspraak te word. Die sin van die lewe kan nie lể in wat die mens daarvan maak nie, maar lê daarin dat die lewe in ooreenstemming met sy oorspronklike karakter as geskenkte lewe geleef word. Die lewe, so 'n lewe, is self die sin van die lewe. Die gelowige ontvang sekerheid waar geen sekerheid te sien is nie. Die menslike selfverstaan soos deur Dreyer (1972:61) verwoord, naamlik '[k]an 'n mens ooit werklik geborge wees, waarlik die sinvolheid van die lewe en die geskiedenis aanvaar, solank daar geen objektiewe geldigheid en sinvolheid bestaan nie?' word by die keerpunt gebring. Geborgenheid val nie saam met die vind van een of ander aantoonbare sin van die lewe nie, maar in die oorgawe aan die Gewer van alle lewe wat aan ons laat verkondig dat die sin van die lewe die lewe self is.

\section{MEDITASIE: DIE HOORDER}

Hemelvaartdag het sy naam te danke aan die verouderde wêreldbeeld. Die vrae en twyfel wat mense het oor die hemel en hemelvaart stel die prediker op hierdie dag voor die vraag of hy toegewings aan die verouderde wêreldbeeld gaan maak en of hy sy hoorders ernstig sal opneem. Dat die tema so prominent aan die dag hemelvaart gekoppel is, maak dit raadsaam dat die prediker nie eintlik anders kan as om die bul by die horings te pak en die tema te behandel nie. So het Schmithals (1982b) sy preekbeurt waargeneem op 'n wyse wat laat sien dat die gesteldheid van die moderne mens sy erns is.

Schmithals maak geen toegewing aan die mitiese wêreldbeeld nie en stel vas dat die geloofsmatige betekenis nie lê in die voorstelling van 'n verandering van plek nie (vgl Schmithals 1979:747). Schmithals wil die hemelvaart nie geisoleerd verstaan nie en bring dit in verband met die paasgebeure. Saam vorm dit die een gebeure van Jesus se verhoging, sy bekleding met mag (Schmithals 1982a:23; vgl 1988:377). Die 'sit aan die regterhand van God' word in die oudste bewoording van die hemelvaart as verduideliking daarby genoem: ' $\mathrm{Hy}$ is in die hemel opgeneem en het gaan sit aan die regterhand van God' (Mark 16:19). Die beeld van die sit aan die regterhand wil sê dat God deur Christus die wêreld regeer. Hemelvaart en die sit aan die regterhand van God is aanskoulike voorstellings van die kerklike belydenis dat Jesus die Here is. Die tema van hemelvaart is: Jesus is die Here (Schmithals 1982b). Op soortgelyke manier het Bonhoeffer (1970:63) die hemelvaartgeloof beskryf as die geloof in Christus se regering van die wêreld en die lewe.

Schmithals maak gebruik van die insigte van die teologie van die woord waarvolgens die evangelie telkens in tydelike vorm geformuleer is en word. Vir die mense wat vertroud was met die mitiese wêreldbeeld kon die evangelie as hemelvaart geformuleer word. Maar die uitgelegdheid as hemelvaart is nie self die evangelie 
nie, net die formulering daarvan. Daarom gaan Schmithals gedistansieerd om met die formulering van die evangelie as hemelvaart. Die hemelvaart is uitdrukking van die Christus-gebeure.

Van Selms (1955) het 'n ander weg gevolg om by die boodskap van die hemelvaartfees uit te kom. Ons gee 'n begronding en gevolgtrekking in sy argumentvoering weer:

Om dit skerp te sê: Christus het as mens na die hemel opgevaar. Op die Kersdag kom God na die aarde, maar op die hemelvaartsdag is dit nie God wat na die hemel terugkeer nie, maar die Godmens, Jesus Christus. Hy neem van die aarde sy mensheid saam na die hemel.

Dit wil dus sê dat daar vir die mens plek en bestaansmoontlikheid in die hemel is. Die mens wat ons hier ken as ' $n$ wese wat aan die tyd en ruimte gebind is, vind in die ewigheid, bo tyd en ruimte, 'n Vaderhuis. Die mensheid is nie reddeloos aan hierdie wêreld en sy verganklikheid oorgegee nie, maar kan plek vind in die onverganklike Ryk van God.

Hieruit is dit duidelik dat Van Selms nie onderskei tussen die evangelie en die formulering daarvan nie; vir hom is die evangelie identies aan die formulering. Die evangelie is nie net tydelik uitgelê nie, maar vir altyd uitgelê. Die teologie van die woord speel hier geen rol nie. Van Selms se oordenking stel die objektiewe daad van God wat vir die mens betekenis het. Die verkondiging is nie self deel van die daad van God nie, maar vertel daarvan. Die wyse van openbaring is 'n objektiewe daad wat tussen Jesus en God plaasgevind het ten gunste van die mens. Die gebeure speel aanvanklik buite die menslike ervaring af en word dan binne die veld van menslike bevatlikheid gebring deur die stel daarvan. In hierdie voorstelling word twee maniere van glo veronderstel. Die aanvanklike geloof moet die berig van Jesus se opgaan na die hemel vir 'n feitelike bonatuurlike waarheid hou en daarin 'n teken van hoop sien. Die verdere geloof bestaan dan in die hoop self, dit wil sê dat die mens sal hoop (vgl Bultmann 1980:300).

Die identifisering van die evangelie met die uitleg daarvan moet noodwendig die inhoud van die evangelie verander. Die krisis wat die verkondiging nou vir die hoorder inhou, is dat hy gelowig van 'n hemel moet kennis neem wat nie meer vir hom bestaan nie, want in sy lewe reken hy nie met 'n hemel bokant die aarde, al moet die hemel hoër wees as gewoonlik 'bo tyd en ruimte', wat ook as die huis van God dien nie. Maar die ergernis wat so voor die hoorder gelê word, is nie waarlik 'n krisis nie, eerder 'n ongemaklikheid, want al wat van hom verwag word is om sy wêreldbeeld te verander, te verouder. Hy self in sy selfverstaan word nie aangevat 
nie. Die teologie van die krisis kry so 'n onkritiese betekenis. Die inhoud van die openbaring is hiervolgens die mitologiese wèreldbeeld.

Dit is interessant om op te let waaruit, volgens Van Selms, die ellende van die mens bestaan: Waaruit moet die mens verlos word? Van die 'wêreld en sy verganklikheid'. Wêreld word hier nie verstaan as die wêreld wat die mens rondom en in hom bou waar hy op sy eie moontlikhede vertrou nie, maar as 'n objektiewe verwyderd wees van God. ' $n$ Mens sou dit dus eerder 'n Gnostiese of selfs Apokaliptiese verlossingsvoorstelling moet noem as ' $n$ Christelike. En as hy eenmaal tot kennis gekom het dat daar vir hom 'plek en bestaansmoontlikheid in die hemel is', hoef hy nie weer van nuuts af te begin en te wag dat God aan hom genade moet betoon nie; hy weet klaar dat hy deel is van die verlossingsisteem. Die oomblik van waarheid waarin die mens die toegesproke genade van God aanvaar en wat so belangrik in die dialektiese teologie is, is hier afwesig.

Uit die voorafgaande is dit duidelik dat die meditasie reeds by die eksegese teenwoordig is. Die verstaan beweeg in 'n sirkel, sodat die einde reeds deel van die begin uitmaak. As die teoloog uit angs vir die onsekere van 'n historiese bestaan, sy sekerheid in 'n objektiewe sisteem soek, sal die soeke na 'n sisteem die uitslag van die eksegese bepaal.' Waar die teologie van die woord die toegang tot die kerklike boodskap is, sal die preek reg laat geskied aan die mens in sy historiese vryheid en verantwoordelikheid en die tydelikheid van sy spreke oor God. Dat die hermeneutiese proses in 'n sirkel beweeg, is nie opsigself ' $n$ probleem nie. Die belangrike is met watter benadering, hermeneutiese beginsel, 'n mens die sirkel ingaan.

Van Selms veronderstel 'n objektiewe daad van God op grond waarvan die hemelvaart betekenis vir die mens het. Hy onderskei tussen Christologie en soteriologie. Die Christologie vorm die objektiewe basis vir die daaruit voortvloeiende verlossing. Schmithals weer verstaan God se handeling in Christus as 'n daad wat van die begin af aan die mens en tot sy voordeel gedoen is, want die boodskap praat nie net van God se daad in Christus nie, maar is self hierdie daad. As Goddelike heil kan die heil nie objektief aangetoon word nie. In die woord wat Hom verkondig, is Christus teenwoordig as die Here wat op heerskappy oor die mens aanspraak maak. Die uiterlike woord wat die mens aanspreek, is die waarborg dat God se daad die mens se gelowige aanvaarding daarvan voorafgaan, maar in die verkondiging val Christologie en soteriologie saam. Eers in die geloof bely die mens dat Jesus die Here is.

In vergelyking met Van Selms gaan Schmithals (1982b) radikaal te werk en verklaar reg aan die begin van sy preek dat 'n ouwèreldse hemelvaart vandag nie meer voorstelbaar is nie en doen van die beeld afstand om by die saak uit te kom. Die saak moet uitgelê word. En met die verskuiwing na die saak toe, kom 'n ander aan- 
stoot as dié van die wêreldbeeld na vore. Dit is nie die wêreldbeeld van die mens wat aangepas word nie; die selfbeeld van die mens word in 'n krisis gedompel. Die werklike aanstoot van die hemelvaartfees is dat gesag en outoriteit, heerskap nie meer in aanvraag is nie. Schmithals verduidelik hierdie aanstoot deur daarop te wys dat die mens wat hom van alle gesag losmaak, tog nie van homself loskom nie. Die mens word sy eie 'Here'. En vir die mens wat hom in sy eie gevangenis gevange hou, word die vryheid van die kindskap van God aangebied in die aanspraak van die hemelvaartboodskap: 'Jesus is die Here.' Op natuurlike wyse gaan Schmithals voort om na aanleiding van vadersdag, wat op dieselfde dag val, oor ouerlike gesag, in die lig van die heerskap van Jesus Christus te reflekteer: Net hy wat 'n Vader het, kan self vader wees.

Bostaande kan dien as illustrasie van hoe Schmithals mediteer en dat dit nie 'n afsonderlike, tweede stap na die eksegese van die teks volg nie, maar in werklikheid daarmee vervleg is. Deur die hemelvaart self te verstaan, vertaal hy dit vir die mens van vandag. Wat Van Selms betref, wil ek nie die indruk agterlaat dat hierdie een oordenking van hom verteenwoordigend van sy hele teologie is nie. 'n Afsonderlike studie behoort daaraan gewy te word. Sy oordenking is wel verteenwoordigend van wat 'n mens buite die teologie van die woord aantref. Van Selms het getrou gebly aan die gereformeerde beskouing van die hemelvaart (vgl Chantepie de la Saussaye 1874:13-15 vir hierdie beskouing).

\section{DIE ROL VAN DIE HISTORIESE SITUASIE VAN DIE TEKS IN DIE PRE- DIKING}

Die histories-kritiese eksegese gaan uit van die standpunt dat die woorde van die Skrif nie aan die huidige leser geadresseer is nie, maar aan die destydse lesers in hulle spesifieke omstandighede. Die oorspronklik geadresseerdes mag nie uit die oog verloor word, as die boodskap van die teks verstaan en uitgelê moet word nie. Hoewel hierdie insig min of meer gemeenplaas in die teologie is, word dit selde met oortuiging deurgevoer. Bultmann het met onderskeiding as voorstander van die histories-kritiese metode gewerk en tog was hy nie deurgaans konsekwent daarmee nie. Om Bultmann te gebruik om so 'n gebrek aan te dui, wys net op die groot uitdaging wat voor die histories-kritiese eksegeet lê. 'n Preek wat Bultmann na anleiding van 'die laaste oordeel' (Matt 25:31-46) gelewer het, dien as voorbeeld.

In Matteus 25:31-33 staan daar: 'Wanneer die Seun van die mens in majesteit kom en al die engele saam met Hom, sal Hy op sy koninklike troon gaan sit. Al die volke sal voor Hom bymekaar gebring word, en Hy sal die mense van mekaar skei soos 'n wagter die skape van die bokke skei. Die skape sal Hy regs en die bokke links van Hom laat staan.' Bultmann (1962:48) volg 'n kortpad tussen die teks en 
die hoorders van vandag deur die teks uit te lề as 'n vermaning om tot 'n beslissing te kom, sonder om die situasie van die skrywe in ag te neem. Hy neem aan dat die teks sy uitsprake binne die hedendaagse situasie maak. Die hoorders moet hulleself vind in die geseëndes en vervloektes, wat verwonderd en verbaas staan oor wat hulle gedoen het. Die verbasing kom daarvandaan dat 'n mens onbewus is van wat hy doen. Die verhaal beklemtoon hoe belangrik die gedrag is waarvan ons nie kennis dra nie. Bultmann besef terdeë hoe vreemd hierdie verklaring vir 'n Bybelse teks is, maar gaan daarmee voort: Gewoonlik verwag Jesus se woord 'n beslissing van nugtere mense, maar vandag lei die teks ons om aandag te gee aan die belangrikheid van ons gedrag waarvan ons nie weet nie. Ook Bonhoeffer (1975:39-40) maak gebruik van die uitleg dat sowel die gemeente as die Fariseërs nie weet dat hulle goed doen en kwaad doen nie. Die onbewuste goed doen en kwaad doen is ter sake.

Nadat hy vasgestel het dat dit gaan oor die onbewuste gedrag, spreek Bultmann diegene salig wat toegee dat, al probeer hulle ook hoe hard, hulle nooit daarin slaag om reg aan die Christelike lewe te laat geskied nie. Wat saak maak, is nie of hulle slaag nie, maar wat hulle in hulle binneste kern is. Vervolgens word die ondogmatiese Christene gelukkig genoem en daarna die siekes en ou mense wat nie meer veel kan uitrig nie (Buitmann 1962:48-49).

Die teks troos egter nie net nie, maar is veral as waarskuwing bedoel. Die Fariseërs wat trots is op hulle bewustelike werke, moet hoor dat dit nie saak maak nie. Al wat beoordeel word, is die onbewuste van die mens (Bultmann 1962:49-50).

Bultmann (1962:50-51) koppel die onbewuste gedrag van die mens aan die gereedheid vir elke oomblik van die lewe. Wanneer die mens afstand doen van die bewustelike berekening, gaan hy oop vir die geleentheid van die oomblik. So bly Bultmann getrou aan die eksistensialisering van die Bybelse boodskap.

Die onbewuste lewe van die mens wat beoordeel word, identifiseer Bultmann (1962:51) as liefde, want al die onbewuste goeie werke wat genoem word, is liefdeswerke. En die bron van ons liefde is die boodskap dat God ons liefhet. So korreleer die openbaring met die menslike eksistensie.

Van Schmithals het ek nie 'n preek oor hierdie teks nie; hy het egter wel 'n preekskets gepubliseer (Schmithals 1985b; vgl 1985a:377) waarin hy wenke gee oor hoe 'n mens met hierdie gedeelte in 'n preek te werk kan gaan. Hy situeer die teks in die omstandighede van die aposunagogos: Die Joodse vyandskap teen die kerk dryf die gemeente uit die juridiese beskutting van die Jodedom, sodat die vrystelling van die keiserkultus nie op die Christene van toepassing is nie. Die vervolging begin, primêr om godsdienstige redes. Matteus beveel in hierdie omstandighede by die gemeente aan om ook die ander wang te draai. Dit beteken egter nie dat hulle van die toneel moet padgee nie. Soos die stad wat op 'n berg lê, gaan hulle voort 
om die beskuldigings wat teen hulle gemaak word, dood te leef. 'Die volke', dit wil sê die nie-Jode, wat hulle oor die geringstes, dit wil sê die Christene, ontferm, sal hulle loon ontvang wanneer hulle by die laaste oordeel verwonderd moet ontdek dat die Here, wat deur die kleinstes aanbid word, ook die Regter oor die wêreld en die Koning in die ryk van God is. Matteus bemoedig sy gemeente deur die belofte wat in hierdie verhaal gemaak word en die gemeente kan in dankbaarheid die belofte aan hulle helpers, veral die heidense godvresendes, deurgee. Schmithals beveel aan dat 'n teksgebonde preek die hoorders in die destydse omstandighede moet inlei. Die doel van so ' $n$ inleiding is om die versmelting van die destydse situasie met dié van vandag, in die gang van die preek, voor te berei. 'n Mens kan hier weer oplet dat die rekonstruksie van die situasie gelyktydig plaasvind met die interpretasie in die hede. Teoreties kan hierdie twee stappe onderskei word, maar in die toepassing is hulle nie te skei nie.

Dit word ook duidelik dat Schmithals oortuig is dat die historiese eksegese reeds by die saak is wat die prediker en die gemeente raak. Daarom kan die gemeente met die historiese teks gekonfronteer word. Die bedoeling van die eksegese is nie om te verstaan wat was nie. Dikwels word eksegese so aangebied sonder dat die preek daaruit voortkom. In so 'n geval het die eksegese misluk. Bybelse tekste maak die aanspraak om hier en nou verstaan te word. As verstaan van die teks moontlik is, sal daar vergelykbare lewensfenomene in die spel kom wat die afstand tussen die tye, destyds en vandag, oorbrug.

Die verbindende faktor tussen die destydse situasie en die van vandag, vind Schmithals in die dogmatiese uitspraak wat die vertelling maak, naamlik dat daar oor die volke geoordeel word na aanleiding van hulle gedrag teenoor die Christene. Dit impliseer dat die wêreld bestaan ter wille van die kerk en nie ter wille van homself nie. Die Christene leef nie van eie menslike moontlikhede nie, maar van die krag wat van God af kom. In hierdie sin het Matteus die uitdrukkings oor die kerk gemunt: 'Julle is die sout van die aarde' en 'julle is die lig vir die wêreld'. Die doel van die wêreld is nie die lewe uit eie krag nie, maar van die genade van God. Die mens is nie die hoop vir die wêreld nie. Dit sal ook nie help om die mense in goeies en slegtes in te deel en van die goeies die heil van die wêreld te verwag nie. Die heil kom van buite die mens. As die Christene die lig vir die wêreld genoem word, verwys dit uitsluitlik na die handeling van God tot heil van die wêreld. Die Christene verkondig ' $n$ boodskap wat die wêreld nie self tot uiting kan bring nie: 'My genade is vir jou genoeg.' Reeds die situasie van vervolging maak dit duidelik dat die Christene nie na hulleself en na eie krag verwys nie, maar na die krag van God. Geen elitêre theologia gloriae word voorgedra nie. 
Die situasie van die hoorders van die preek word nie deur sosiologiese analises bepaal nie, maar deur die konkrete wèreld-, God- en selfverstaan wat geld. Teen hierdie verstaan word die teks ingespan. Almal se skuld word uitgewys: 'Daar is donkerte oor die aarde, duisternis oor die nasies' (Jes 60:2a). Die teks gee die aanleiding daartoe om ons huidige situasie te begryp as een waarin ons as gelowiges of as ongelowiges optree. En hierdie aanleiding is die toesegging van heil. Die toesegging van heil maak die situasie uit en die beslissing waartoe gekom word, bepaal die situasie. Die gelowiges sien hulleself in die lig van God se handeling en weet dat hulle die 'kleinste broers' van die Regter en Koning is wat nie aan mag en prestasie die hoogste plek toeken nie, maar aan geloof, hoop en liefde.

Schmithals meen dat die etiese aspek nou ook tot sy reg kan kom. Die mense buite die gemeente ontferm hulle oor die vervolgdes omdat 'hulle julle goeie werke kan sien en julle Vader wat in die hemel is, verheerlik' (Matt 5:16b). Die goeie werke is nie werke van vermeteles wat hulleself tot die sout van die aarde verklaar nie, maar van geringes, gevangenes, dorstiges, naaktes: werke van mense wat weet hoe afhanklik hulle van God is - werke van liefde, trou en waaragtigheid. Liefde, trou en waaragtigheid is die kernstuk van Christelike sedelikheid soos Matteus dit leer (vgl Schmithals 1985a:381). Al sou die omstandighede waarin die kerk vandag leef, soveel gunstiger wees as destyds, is die enigste geseënde weg dié van liefde, trou en waaragtigheid.

So verhoed die teks, soos deur Schmithals uitgelê, dat geloof in etiese aktiwiteit verander word. Geen konkrete dade word aanbeveel nie. Die vraag na die regte gedrag word beantwoord deur na mense te verwys wat weet hoe afhanklik hulle van God is. Om in liefde, trou en waaragtigheid te lewe en jou aan God toe te vertrou, is twee gelykwaardige aspekte van een Christelike lewe. Etiek is dogmatiek. Die imperatief is self evangelie. Met sy vertroue op homself en op sy eie werk sou die mens nie meer voor God staan nie. Nie die eindpunt van iets wat gedoen moet word, is konkreet nie, maar die heil is self konkreet. Dit gaan om die hele mens voor God.

Schmithals meen dat dit nie so maklik is om die 'geseëndes van die Vader' te identifiseer, soos wat Matteus dit kon doen nie. In 'n waarskynlike verwysing na Bultmann (1962) wil hy ook nie die onbewuste Christene sonder meer geseëndes noem nie. Die preek is daarop uit om geloof te stig en nie om die belangrikheid van die mens se onbewuste innerlike uit te lig nie. Die gemeente behoort nietemin te weet dat God groter is as ons hart wat ons veroordeel. Die beste sou wees as die Christen "n geseënde van die Vader' in elke medemens wil vermoed en so op homself let in sy ontmoeting met sy naaste dat hierdie seën tot deurbraak kom, tot lof van die Here. 


\section{TEN SLOTTE}

Bultmann se groot bydrae tot die teologie van die woord lê daarin dat hy nuut gemediteer het. Hy het op 'n verrassende wyse die hoorder van die Christelike boodskap na vore gebring. Die hoorder van die preek was vir hom van die begin af teenwoordig by die lees van die ou Bybelteks.

Schmithals gaan akkoord met hierdie meditasie en sy bydrae tot die nuwere teologie lê verder daarin dat hy nuut eksegetiseer het. Hy slaag daarin om nie net die situasie waarin die teks ontstaan het, aan te toon nie maar om hierdie faktor 'n beslissende rol by die verstaan van die teks te laat speel. Die teks is deur die boodskap van die kerk in ' $n$ bepaalde historiese omstandigheid in aansyn geroep. Die historiese feite is onontbeerlik om die inhoud van die teks te begryp soos die skrywer dit ontvou het, want die teks is dokument in diens van die kerklike boodskap in bepaalde omstandighede. 'n Mens kom onder die indruk dat Schmithals 'n eenheid van historiese en teologiese eksegese bereik het wat nog nie vantevore so uitgespel is nie.

\section{Literatuurverwysings}

Bonhoeffer, D 1970 (Bethge, E [Hrsg]). Widerstand und Ergebung: Briefe und Aufzeichnungen aus der Hafi. Neuausgabe. München: Kaiser.

..- 1975 (Bethge, E [Hrsg]). Ethik. 8. Aufl. München: Kaiser.

Bultmann, R 1926. Die Frage der 'dialektischen' Theologie: eine Auseinandersetzung mit Peterson. $Z Z 4 / 1,40-59$.

-.- [1928] 1972. Die Bedeutung der 'dialektische Theologie' für die neutestamentliche Wissenschaft, in Bultmann, R, Glauben und Verstehen: Gesammelte Aufsätze, I, 114-133. 7. Aufl. Tübingen: Mohr.

--- 1962. Sermon, in Gollwitzer, H \& Traub, H (Hrsg), Hören und Handeln: Festschnift für E. Wolf zum 60. Geburtstag, 47-51. München: Kaiser.

--- 1980. Theologie des Neuen Testaments. 8. Aufl. Tübingen: Mohr. (UTB 630.)

Chantepie de la Saussaye, D 1874. De brief aan de Hebreën voor de gemeente uitgelegd. 2e druk. Amsterdam: Höveker \& Zoon.

Dreyer, P S 1972. Waarde en geskiedenis. HTS 28/2, 51-62.

Dreyer, T F J 1989. Poging tot 'n herdefinisie van die prediking binne die raamwerk van die Reformatoriese teologie. HTS 45, 350-369.

Engelbrecht, B J [1962] 1982. Wat is die reg en die vryheid van die eksegeet? in Versamelde opstelle, Deel 2, 51-67. Pretoria: Universiteit van Pretoria. [Ook gepubliseer in HTS 42 (1986), 485-501.] 
Oberholzer, J P 1990. Ou-Testamentiese perspektiewe op die definisie van die prediking. HTS 46, 647-655.

Schmithals, W 1953. Die Bekehrung des Zachäus: Lk 19,1-10. RKZ 24, 534-536.

-- 1967a. Zur gegenwärtigen Predigtnot und ihrer überwindung. KiZ 3, 94-102.

--- 1967b. Kerygma und Heilstatsache: Kein anderes Evangelium. KiZ 11, 493 500.

-.- 1967c. Die Wahrheit der Heiligen Schrift und das Konzil, in Hampe, J C (Hrsg), Die Autorität der Freiheit: Gegenwart des Konzils und Zukunft der Kirche im ökumenischen Disput. Bd 1, 197-208. München: Kösel.

-.- 1970a. Das Christuszeugnis in der heutigen Gesellschaft: Zur gegenwänigen Krise von Theologie und Kirche. Hamburg: Reich. (EZS 53.)

-.- 1970b. Sinn und Aufgabe der modernen Theologie. Die Spur 3, 80-85.

--- 1970c. Die Frage nach Gott im Neuen Testament. Die Spur 5, 176-185.

--- 1972. Jesus Christus in der Verkündigung der Kirche: Aktuelle Beiträge zum notwendigen Streit um Jesus. Neukirchen-Vluyn: Neukirchener Verlag.

--- [1970] 1972a. Das Bekenntnis zu Jesus Christus, in Schmithals, 1972:60-79.

--- [1970] 1972b. Erwägungen zur Didaktik des Theologiestudiums, in Schmithals, 1972:187-205.

--- [1971] 1972c. Politische Theologie, in Schmithals, 1972:118-143.

--- 1973. Krise und Kritik des Religionsunterrichts. Die Spur 4, 120-127.

-.- 1975. Predigt über Mk 10,46-52. Gemeindebrief der Deutschen Evangelischen Gemeinde Rotterdam 3,1-4.

--- 1979. Das Evangelium nach Markus. Gütersloh: Mohn. (ÖTK 2/1;2/2; GTBSiebenstern 502, 503.)

--- 1980a. Das Evangelium nach Lukas. Zürich: Theologischer Verlag. (Zürcher Bibelkommentare: Neues Testament 3.1.)

- 1980b. Die theologische Anthropologie des Paulus: Auslegung von Röm 7,17-18, 39. Stuttgart: Kohlhammer. (Urban-Taschenbücher/Kohlhammer Taschenbücher 1021.)

--- 1981. Von dem Sohne Gottes, in Selge, K C \& Karzig Ch (Hrsg), Es wird bei uns gelehrt...: Berliner Predigten 1980 über das Augsburger Bekenntnis von 1530, 22-27. Berlin: CZV-Verlag.

--- 1982a. Die Apostelgeschichte des Lukas. Zürich: Theologischer Verlag. (Zürcher Bibelkommentare: Neues Testament 3.2.)

-. 1982b. Himmelfahrt. Berliner Rundfunkpredigt, 20. Mai, als Ms. vervielfältigt.

-- 1984. Gedanken zum Pfingstfest. Der Tagesspiegel 10. Juni 1984.

--- 1985a. Einleitung in die drei ersten Evangelien. Berlin: De Gruyter. (De Gruyter Lehrbuch.) 
Schmithals, W 1985b. Matthäus 25,31-46, in Anregungen zur Predigt am Volkstrauertag 1985, Hrsg von VDK. Kassel: Hessen.

-- 1986. Berliner Rundfunkpredigt: Wir leben oder wie sterben - wir gehören Gott allein. 13. April 1986. Ev. Rundfunkdienst in der Berliner Arbeitsgemeinschaft für Kirchliche Publizistik.

-- 1988. Der Römerbrief: Ein Kommentar. Gütersloh: Mohn.

Van Selms, A 1951. Leersuccessie als Gezagsvorm. NTT 5, 257-276.

--- 1955. Hemelvaart. Die Vaderland $19 \mathrm{Mei}, 9$.

Vinet, A 1875. Homiletiek of theorie der prediking, uit het Fransch vertaald en met aantekeningen voorzien door $\mathrm{E}$ Moll. Tweede nieuw bewerkte druk. Tiel: Campagne. 